\title{
Half-Life of Glyphosate on the Control of Water Hyacinths in Water Tanks
}

\author{
Evandro L. C. Souza1 ${ }^{*}$, Luiz L. Foloni' ${ }^{1}$ José T. Filho', Edivaldo D. Velini², \\ Luis M. Siono², José R. M. Silva² \\ ${ }^{1}$ School of Agricultural Engineering, State University of Campinas, Campinas, Brazil \\ ${ }^{2}$ Department of Plant Breeding an Protection, College of Agricultural Sciences, São Paulo State University, Botucatu, Brazil \\ Email: *elcorrea77@hotmail.com
}

How to cite this paper: Souza, E.L.C., Foloni, L.L., Filho, J.T., Velini, E.D., Siono, L.M. and Silva, J.R.M. (2017) Half-Life of Glyphosate on the Control of Water Hyacinths in Water Tanks. Journal of Water Resource and Protection, 9, 470-481. https://doi.org/10.4236/jwarp.2017.95030

Received: January 31, 2017

Accepted: April 17, 2017

Published: April 20, 2017

Copyright $\odot 2017$ by authors and Scientific Research Publishing Inc. This work is licensed under the Creative Commons Attribution International License (CC BY 4.0).

http://creativecommons.org/licenses/by/4.0/

\begin{abstract}
The present study had the purpose to assess the behavior of the herbicide glyphosate in the control of water hyacinths, in a water environment through half-life, in a controlled and closed experimental field, in order to contribute to the analysis of the risk of the environmental impact of the use of this product. Eight fiber-cement tanks with the storage capacity of 250 liters were used under the conditions without water flow and without replacement of water. The experiment was designed in two treatments with four repetitions, the first being colonized by water hyacinths and the second without the presence of the macrophyte. The recommended dose, according to the manufacturer, was 7.0 L.ha ${ }^{-1}$ or $3402 \mathrm{~g} \cdot \mathrm{ha}^{-1}$ of equivalent acid. For the application in the tanks, we have used carbon dioxide $\left(\mathrm{CO}_{2}\right)$ precision equipment, providing a flow

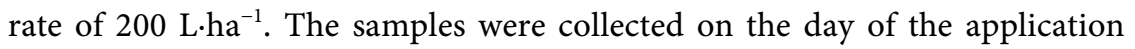
(day zero) and 2, 4, 8, 16, 32 and 64 days thereafter (DAP). The method used for determination of residues was by high performance liquid chromatography (HPLC) and mass spectrometry with a mass selective detector. From the mathematical model of charge decay, the half-life of glyphosate in water was estimated to six days for the tanks without water hyacinths and sixteen days for the tanks colonized by macrophytes. The result obtained permits to conclude that the glyphosate in water is quickly degraded in closed water environments and does not leave residues that would prevent its use.
\end{abstract}

\section{Keywords}

Herbicides, Eichhornia crassipes, Residues, Environmental Impact

\section{Introduction}

The chemical method, which advocates the use of specific herbicides to control aquatic plants, has been the most widely used in different places in the world due 
to low cost and especially the speed, easy of application and control efficiency [1] [2] [3]. The world's most used herbicides to control aquatic macrophytes are: 2,4-D; diquat; endothall, a copper-based compound; fluridone; imazapyr and glyphosate [4]. The production of knowledge in this area in Brazil has been small, given the prohibitive legislation in loco studies [5]. The studies developed in the country, reason of that prohibition, have been performed in controlled environments and in closed systems, with results showing herbicide use efficiency in controlling several species of aquatic plants [6] [7] [8] [9].

According to [5], the chemical control of aquatic plants is restricted to a few herbicides due to restrictions imposed by legislation, to the environmental impact, to the market size for the private sector and to the application of technology. The environmental restrictions are the most important factors because the waterways are used for many purposes, such as a source of water for human and animal consumption, crop irrigation, leisure activities, navigation and hydraulic energy generation.

Although the different work done to prove efficiency of the use of various active ingredients in the control of aquatic macrophytes, few environmental impact studies have been conducted. Environmental impact studies have been little exploited to date due to the limitation of the use of chemicals in aquatic environments [10] for the protective intervention of IBAMA (Brazilian Institute of Environment and Renewable Natural Resources). However, much more important than the action of the product in the management of macrophytes is its direct action on integration with the environment in question. Among studies performed, the ones mentioned are those monitoring the effects of the herbicides on the quality of the water and the sediments [11] [12] [13] [14] and more rarely those that have investigated, besides the water quality parameters, the molecule residues in plants and in the water, in the reservoirs or mesocosms [13] [14] [15].

Thus, an accurate study of the use of herbicides to control the aquatic macrophytes in closed aquatic environment, from the point of view of environmental impact, may systematize data scientifically treated, and form knowledge to evaluate its behavior within the environment. Therefore, it will contribute in the definition of public policies by regulatory agencies in facing the serious problem represented by the uncontrolled proliferation of macrophytes in water bodies, particularly, by obstruction of the turbines in reservoirs for power generation. This fact has a direct effect on the production cost of electrical energy, which is essential for economic, technological and social development of the country.

In the present experiment the herbicide glyphosate was chosen because it is registered in several countries for the control of aquatic macrophytes, being one of the main products studied, used in the world and with great potential in the management of aquatic weeds. Thus, it was chosen to study it in a controlled and closed experimental field, in the management of (Eichhorniacrassipes) in reservoirs. The behavior of the product's half-life was analyzed, aiming to contribute to the risk analysis formulation of environmental impact of the use of 
this product to control aquatic weeds.

\section{Materials and Methods}

The study was developed in the Experimental Area of the Núcleo de Pesquisas Avançadasem Matologia (NUPAM) belonging to the Faculdade de Ciências Agronômicas da UNESP (Department of Agronomic Sciences of the University of São Paulo), Botucatu (SP) campus, during the months from May to November 2011. The local climate, according to the Köppen method, is classified as humid mesotherm (Cfa), presents average temperature of the hottest month above $22^{\circ} \mathrm{C}$ and small water deficiency between April and August. Eight (08) fiber-cement tanks were used, four for each treatment with a storage capacity of 250 liters, without water flow and without replacement of the evapotranspired water ("worst case"). The water supplying the tanks came from the Companhia de Saneamento Básico do Estado de São Paulo (SABESP) (Sanitation Utility of the State of São Paulo). The samples were collected in the lower third of the tanks.

\subsection{Treatments}

The treatments used in the experiment were called: 1-tank without water hyacinths and with application of glyphosate; 2-tanks with water hyacinths and with application of glyphosate.

For the set of conditions of the tanks containing macrophytes, the species analyzed was Eichhorniacrassipes (Mart.) Solms (water hyacinth). The plants were collected from the Tietê River, Botucatu region (SP) and placed in boxes to provide $90 \%$ occupancy of the tank surface.

The herbicide control was carried out by application of glyphosate in the recommended maximum dose since the recommendations for the study of environmental impact are to look for the worst scenario "worst case". According to the former registration of the product, the Rodeo, in Brazil, the recommended dose was $7.0 \mathrm{~L} \cdot \mathrm{ha}^{-1}$ or $3402 \mathrm{~g} \cdot \mathrm{ha}^{-1}$ of acid equivalent. The surfactant Alterbane was added to the herbicide stock at a concentration of $0.5 \%\left(466.6 \mathrm{~g} \cdot \mathrm{L}^{-1}\right)$ [16].

The tanks were sprayed, using the carbon dioxide precision equipment (backpack sprayer), provided with plywood bar containing two flat jet nozzles Jacto XR 110.02, operating at a pressure of $2 \mathrm{kgf} \cdot \mathrm{cm}^{-2}(20 \mathrm{Kpa})$, providing an even distribution of the glyphosate in the tank and a solution consumption corresponding to $200 \mathrm{~L} \cdot \mathrm{ha}^{-1}$. The calibration was performed on site based on the applicator speed in regards to the area worked.

\subsection{Evaluations}

The values obtained in the control efficiency of water hyacinth were submitted to variance analysis and to Tukey test, considering a 5\% level of significance. The evaluations of effectiveness were carried out visually after 2, 4, 8, 16, 32 and 64 days after application (DAA), using percentage scale, where 0 (zero) represents no control and $100 \%$, the total plant control [17].

The water samples to determine the glyphosate residues were collected on the 
day of the application (day zero) and on 2, 4, 8, 16, 32 and 64 DAA, in the morning, always at the same time, at 11 a.m. The depth of the collection was conducted between $15-30 \mathrm{~cm}$ below the water level, and the samples were placed in plastic containers of $200 \mathrm{~mL}$ and stored in a freezer at $-18^{\circ} \mathrm{C}$, in which the residue analyses were subsequently performed.

The concentrations $\left(\mathrm{mg} \cdot \mathrm{Kg}^{-1}\right)$ of glyphosate and AMPA (main metabolite of glyphosate) residues were determined. For determination of compounds in water, the samples were thawed, stirred, and filtered directly on Millex HV filter (Millipore) $0.45 \mu \mathrm{m}$, provided with a $13 \mathrm{~mm}$ durapore membrane, and placed in a $9 \mathrm{~mm}$ amber-colored vial (Flow Supply), with a capacity of $2 \mathrm{~mL}$, for further quantification by LC-MS/MS.

The molecular mass and fragments generated from each molecule are shown in Table 1. The fragment used for quantification of each of the compounds was always the first presented in Table 1, for each compound. The analytical curves for the compounds were constructed in the concentration ranges described in Table 2. The linear model used in the equations was quite adequate.

The method used was by high performance liquid chromatography (HPLC) and mass spectrometer with a mass selective detector, presenting detection limit of compounds at $0.001 \mathrm{mg} \cdot \mathrm{kg}^{-1}$ of the glyphosate.

Before each collection, the volumes of the tanks were measured so that, later, the load (mass) of glyphosate could be calculated in time. The measurement was made with a ruler, considering the relationship between the height/volume of the initial mark of each tank and the height/volume of the mark corresponding to the level of the water at the time of the collection.

The mathematical model of decay was applied to describe the decrease in the concentration of glyphosate and loads in water and to determine the half-life of the compounds.

Table 1. Molecular mass and secondary ions of the analyzed compounds.

\begin{tabular}{ccc}
\hline Compounds & Mass Molecular & Secundary Ions (fragments) \\
\hline \multirow{2}{*}{ Glyphosate } & 169.08 & 63,100 \\
& & 78,900 \\
& & 150,000 \\
AMPA & 62,900 \\
& 169.08 & 78,900 \\
& & 80,800 \\
\hline
\end{tabular}

Table 2. Analytical curves and concentration ranges for each compound analyzed.

\begin{tabular}{cccc}
\hline Compounds & Equation of the line $(y=a x+b)$ & $\mathbf{r}^{2}$ & Linear range $\left(\mu \mathrm{g} \cdot \mathrm{L}^{-1}\right)$ \\
\hline Glyphosate & $\mathrm{y}=371 \mathrm{x}+-349$ & 0.9959 & $4.69-600$ \\
AMPA & $y=138 \mathrm{x}+-316$ & 0.9968 & $4.69-600$ \\
\hline
\end{tabular}


In this experiment two tanks, repetition 1 (No 1) of the treatment plant with glyphosate application and repetition 1 (No 5) without treatment plant application of glyphosate, had to be discarded. The reason was the failure to identify residues in the 1st analysis, immediately after the application, to the tank $\mathrm{N}^{\circ} 1$ and small concentration to the tank $\mathrm{N}^{\circ} 5$; in the following analyses of this tank, no residues were detected. Since the calibration was carried out with water before application, a volume was certainly left in the system, between the bar and the spray nozzles. Moreover, as these tanks were the first to receive the herbicide application and since they were set in sequence in the experimental field, it is easy to understand why no residues were found.

\section{Results and Discussion}

The data obtained in the present experiment with the use of the herbicide glyphosate, in the evaluated dose, showed a percentage of average control of $91.3 \%$, presenting excellent efficiency in the control of the water hyacinths, agreeing with previous works [6] [7] [18].

The values of the glyphosate residues (concentrations and mass) and tank volumes found from dates $0,2,4,8,16,32$ and $64 \mathrm{DAA}$, for both sets of tanks, are presented in Table 3.

Table 3. Values of glyphosate residues (concentration and mass) and tank volumes found from dates 0, 2, 4, 8, 16, 32 and 64 Days after Application (DAA).

\begin{tabular}{|c|c|c|c|c|c|c|c|}
\hline & \multirow[b]{2}{*}{ Days } & \multicolumn{3}{|c|}{$\begin{array}{l}\text { With water hyacinth and with } \\
\text { application of glyphosate }\end{array}$} & \multicolumn{3}{|c|}{$\begin{array}{l}\text { Without water hyacinth and with } \\
\text { application of glyphosate }\end{array}$} \\
\hline & & Vol. (L) & Conc. (mg.kg-1) & Mass (mg) & Vol. (L) & Conc. (mg.kg ${ }^{-1}$ ) & Mass (mg) \\
\hline \multirow{7}{*}{ Tank 1} & 0 & 210 & 0.0413 & 8.6730 & 220 & 0.5060 & 111.3200 \\
\hline & 2 & 210 & 0.0096 & 2.0160 & 220 & 0.2410 & 53.0200 \\
\hline & 4 & 210 & 0.0089 & 1.8690 & 220 & 0.1470 & 32.3400 \\
\hline & 8 & 205 & 0.0039 & 0.7995 & 210 & 0.0751 & 15.7710 \\
\hline & 16 & 180 & 0.0044 & 0.7920 & 195 & 0.0240 & 4.6800 \\
\hline & 32 & 177 & 0.0018 & 0.3186 & 195 & 0.0075 & 1.4625 \\
\hline & 64 & 148 & 0.0017 & 0.2516 & 157 & 0.0033 & 0.5181 \\
\hline \multirow{7}{*}{ Tank 2} & 0 & 210 & 0.1500 & 31.5000 & 220 & 0.4380 & 96.3600 \\
\hline & 2 & 210 & 0.0533 & 11.1930 & 220 & 0.2350 & 51.7000 \\
\hline & 4 & 210 & 0.0473 & 9.9330 & 220 & 0.2250 & 49.5000 \\
\hline & 8 & 205 & 0.0072 & 1.4760 & 215 & 0.2020 & 43.4300 \\
\hline & 16 & 185 & 0.0126 & 2.3310 & 210 & 0.1800 & 37.8000 \\
\hline & 32 & 179 & 0.0121 & 2.1659 & 200 & 0.0126 & 2.5200 \\
\hline & 64 & 148 & 0.0083 & 1.2284 & 182 & 0.0479 & 8.7178 \\
\hline \multirow{7}{*}{ Tank 3} & 0 & 210 & 0.1900 & 39.9000 & 220 & 0.5670 & 124.7400 \\
\hline & 2 & 210 & 0.1390 & 29.1900 & 220 & 0.1700 & 37.4000 \\
\hline & 4 & 210 & 0.0621 & 13.0410 & 220 & 0.0604 & 13.2880 \\
\hline & 8 & 205 & 0.0359 & 7.3595 & 205 & 0.0253 & 5.1865 \\
\hline & 16 & 178 & 0.0287 & 5.1086 & 185 & 0.0082 & 1.5170 \\
\hline & 32 & 170 & 0.0241 & 4.0970 & 180 & 0.0060 & 1.0800 \\
\hline & 64 & 142 & 0.0096 & 1.3632 & 151 & 0.0054 & 0.8154 \\
\hline
\end{tabular}


For those tanks which have not received plants, it can be verified that there was a reduction of loads in $99.5 \%, 90.9 \%$ and $99.3 \%$, in boxes 2,3 and 4 , respectively. As for the tanks colonized by the water hyacinth, the decay in the boxes 2 , 3 and 4 represented, respectively, 97.1\%, 96.1\% and $96.6 \%$.

Likewise the concentration, the average load of glyphosate found in the tanks was greater, sooner after the application, being four times greater where there was no presence of water hyacinth.

However, over time, the mass found in the reservoirs without plants matched the one found in reservoirs containing plants. From 32 DAA onward, the loads found in the tanks without the hyacinth were lower compared to the tank containing plants. The results show that from the metabolism of glyphosate and subsequent control effectiveness or death of the plants onward, the process of decomposition of dead plants released the product into the water in the tanks keeping its content, even if low, but higher thanks that received direct application of the product.

To calculate the AMPA mass in the water in the treatments with and without water hyacinths, the water volumes were used in the tanks in each moment of sample collections and the respective concentrations are presented in Table 4. In the analysis of AMPA parameter, it was expected to see the same behavior in the mass obtained for the glyphosate. However, as can be seen, the larger masses found in the treatment that received the direct application of the product without the presence of water hyacinth, lasted throughout the study period. This behavior suggests that the metabolism of AMPA through the bioaccumulation process is superior to glyphosate. It was not possible to compare results of glyphosate and AMPA loads with other studies, since these are lacking in the available literature.

In order to adjust the data observed of glyphosate residues in water over time, it was used a mathematical model described by Equation (1):

$$
M_{t}=M_{0} \cdot \mathrm{e}^{-\mathrm{kt}}
$$

where: $M_{t}$-glyphosate mass at moment t; $M_{0}$-glyphosate mass at the initial time considered; $k$-decay coefficient and $t$-time.

Applying the Naperian logarithm in the Equation (1), it is obtained:

$$
\ln M_{t}=\ln M_{0}-\mathrm{kt} \text {. }
$$

This equation represents a linear model where the coefficient $(K)$ identifies the mass decay of glyphosate over time. Since three tanks were used in the experiment, the average load was calculated, at times considered of the samples, to determine the average decay value for glyphosate. In order to obtain this value, the logarithm (Ln) was applied to mass values observed (Figure 1) getting the decay value for the tanks without plants of $0.115 \mathrm{day}^{-1}$.

From the value found in the coefficient of average load decay of glyphosate, average values of glyphosate were simulated using the mathematical model of Equation (1) (Figure 2). With this model, it was possible to estimate the half-life of glyphosate applied directly to the water, without the presence of water hyacinths. Considering the estimated average load, the half-life was six days. 


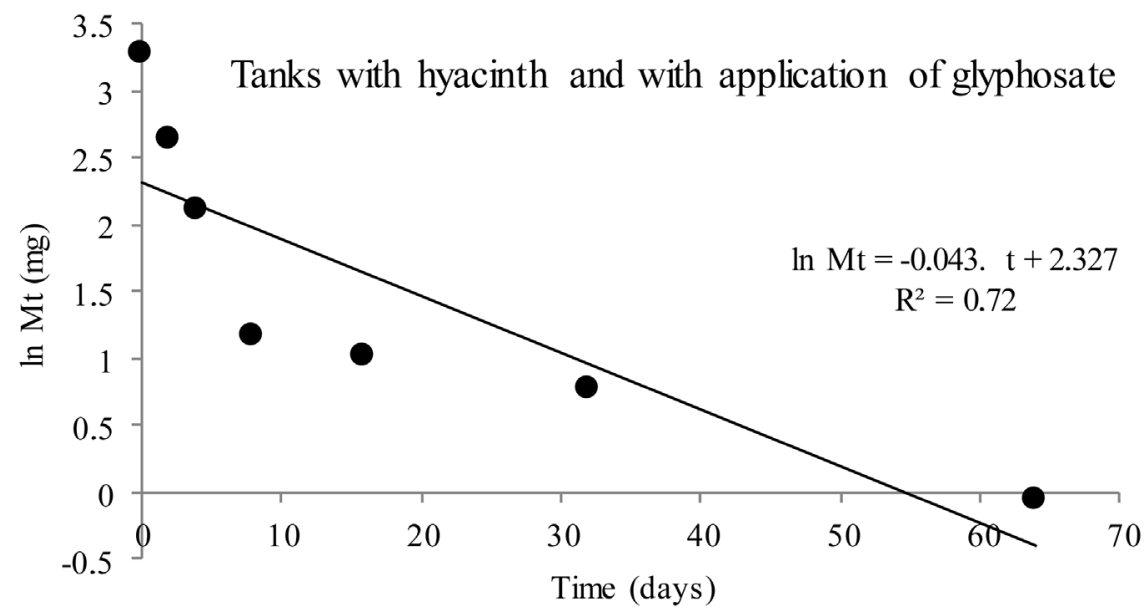

Figure 1. Logarithm of the observed values of average mass (mg) of glyphosate in the tanks with hyacinth and with application of glyphosate.

Table 4. Values of AMPA mass (mg) in the water in the treatments, in each tank, in the treatments with and without water hyacinth from dates $0,2,4,8,16,32$ and 64 Days after Application (DAA).

\begin{tabular}{|c|c|c|c|c|c|c|c|}
\hline & \multirow[b]{2}{*}{ Days } & \multicolumn{3}{|c|}{$\begin{array}{l}\text { With water hyacinth and } \\
\text { with application of glyphosate }\end{array}$} & \multicolumn{3}{|c|}{$\begin{array}{l}\text { Without water hyacinth and } \\
\text { with application of glyphosate }\end{array}$} \\
\hline & & Vol. (L) & Conc. $\left(\mathrm{mg} \cdot \mathrm{kg}^{-1}\right)$ & Mass (mg) & Vol. (L) & Conc. $\left(\mathrm{mg} \cdot \mathrm{kg}^{-1}\right)$ & Mass (mg) \\
\hline \multirow{7}{*}{ Tank 1} & 0 & 210 & 0.0022 & 0.4620 & 220 & 0.0173 & 3.8060 \\
\hline & 2 & 210 & 0.0000 & 0.0000 & 220 & 0.0203 & 4.4660 \\
\hline & 4 & 210 & 0.0026 & 0.5460 & 220 & 0.0231 & 5.0820 \\
\hline & 8 & 205 & 0.0016 & 0.3280 & 210 & 0.0258 & 5.4180 \\
\hline & 16 & 180 & 0.0025 & 0.4500 & 195 & 0.0233 & 4.5435 \\
\hline & 32 & 177 & 0.0000 & 0.0000 & 195 & 0.0168 & 3.2760 \\
\hline & 64 & 148 & 0.0000 & 0.0000 & 157 & 0.0070 & 1.0990 \\
\hline \multirow{7}{*}{ Tank 2} & 0 & 210 & 0.0076 & 1.5960 & 220 & 0.0145 & 3.1900 \\
\hline & 2 & 210 & 0.0042 & 0.8820 & 220 & 0.0072 & 1.5840 \\
\hline & 4 & 210 & 0.0041 & 0.8610 & 220 & 0.0080 & 1.7600 \\
\hline & 8 & 205 & 0.0018 & 0.3690 & 215 & 0.0088 & 1.8920 \\
\hline & 16 & 185 & 0.0038 & 0.7030 & 210 & 0.0075 & 1.5750 \\
\hline & 32 & 179 & 0.0024 & 0.4296 & 200 & 0.0091 & 1.8200 \\
\hline & 64 & 148 & 0.0019 & 0.2812 & 182 & 0.0109 & 1.9838 \\
\hline \multirow{7}{*}{ Tank 3} & 0 & 210 & 0.0110 & 2.3100 & 220 & 0.0207 & 4.5540 \\
\hline & 2 & 210 & 0.0060 & 1.2600 & 220 & 0.0227 & 4.9940 \\
\hline & 4 & 210 & 0.0060 & 1.2600 & 220 & 0.0425 & 9.3500 \\
\hline & 8 & 205 & 0.0043 & 0.8815 & 205 & 0.0295 & 6.0475 \\
\hline & 16 & 178 & 0.0062 & 1.1036 & 185 & 0.0155 & 2.8675 \\
\hline & 32 & 170 & 0.0036 & 0.6120 & 180 & 0.0094 & 1.6920 \\
\hline & 64 & 142 & 0.0031 & 0.4402 & 151 & 0.0049 & 0.7399 \\
\hline
\end{tabular}




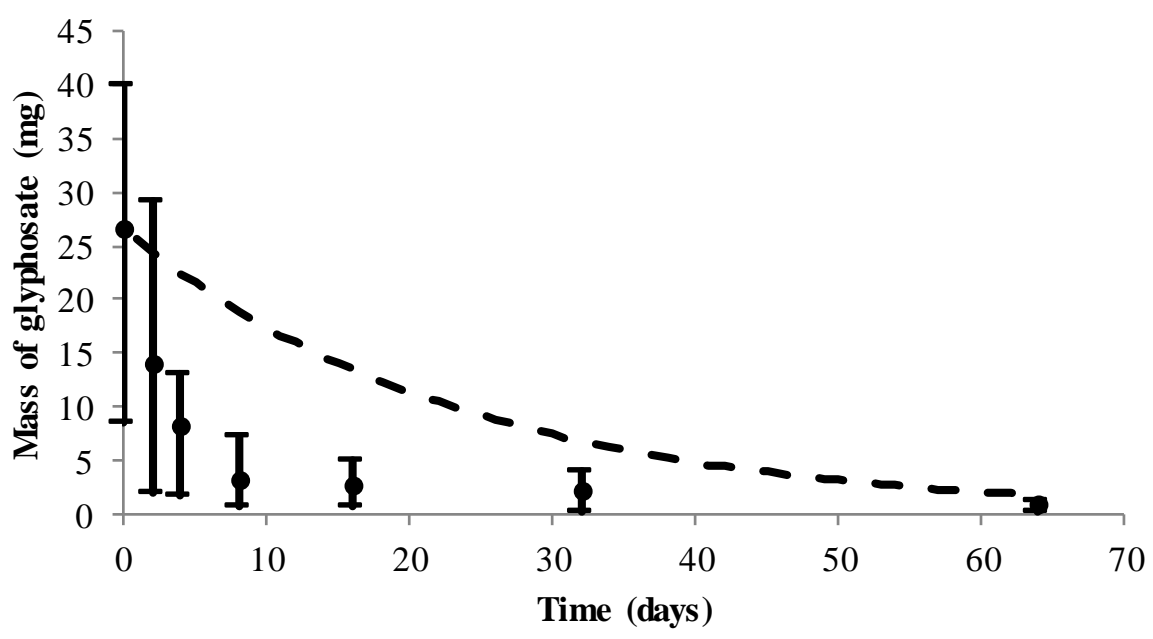

Figure 2. Observed and simulated values of average mass (mg) of glyphosate in the tanks with water hyacinth. Back symbols are values of average mass. Bars are values of average mass maximum and minimum. Dashed lines are simulated values of average mass.

Likewise, the simulation was performed for the tanks receiving the colonization of water hyacinth. The value of the coefficient $K$ and the observed and simulated values of the average load are shown in Figure 3 and Figure 4, respectively. For the conditions of the colonized tanks by water hyacinth, the decay value was calculated equal to $0.043 \mathrm{day}^{-1}$. From Equation (2), it was estimated the glyphosate half-life in water for the treatment with the macrophyte, resulting value of 16 days.

The simulated values for the half-life of glyphosate in water, in both situations, are in accordance to [19] [20] [21] [22] which reports that the average life of the molecule in water can range from 1 to 51 days and to [23], which states that, depending on the conditions of the water body, particularly to those linked to the full microbe activity can vary between a few days to two weeks.

Studies performed in a forest ecosystem [24] [25] have shown that glyphosate had quickly dissipated in the lake waters with many suspended sediments, with the half-life ranging from 1.5 and 11.2 days.

According to FPPD 2012 [26], Mackay et al. 2006 [27] and Gassemini et al. 1981 [28], cited by Mercurio et al. 2014 [29], the half-life of glyphosate in fresh water was estimated between 28 and 87 days.

Furthermore, in the study developed by [30], which was a river water body (open system), it was observed that the half-life of glyphosate in this environment had varied between 60 and 100 hours.

[31] evaluated the environmental fate of glyphosate in the water-sediment system with focus on its microbial metabolization. The results found demonstrated the key role of sediments in its degradation. Also, Glyphosate was detected below detection limit in the water compartment at forty days.

In compliance with [32], this is a low toxicity herbicide that quickly dissipates in the environment. [33] compliments reporting that low bioavailability of glyphosate in natural waters is due to its quick degradation and quick microbial decomposition. 


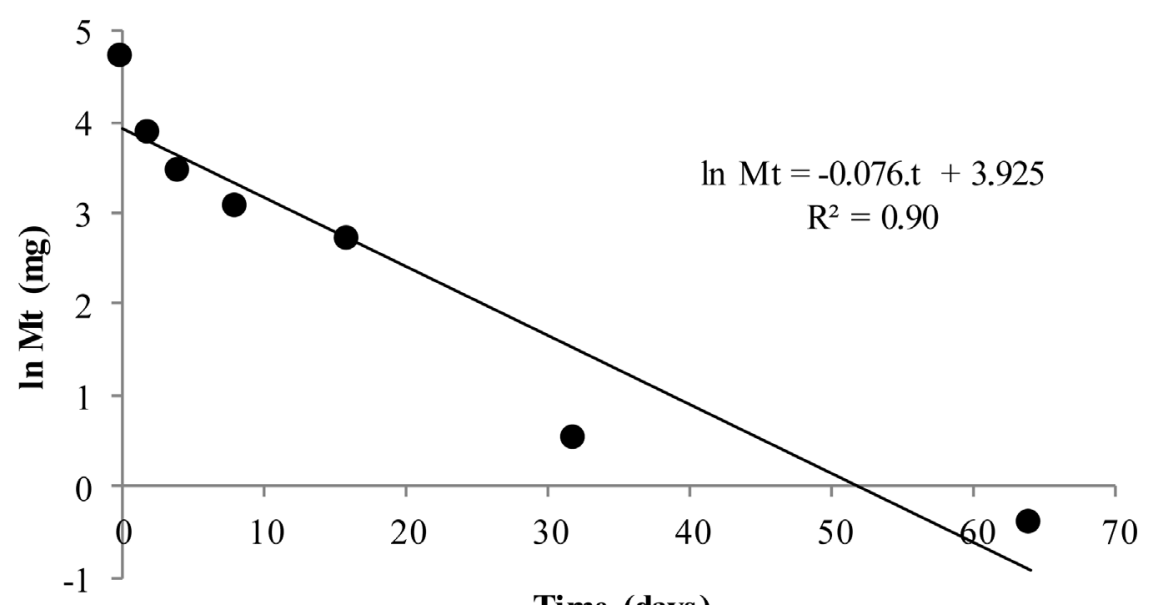

Time (days)

Figure 3. Logarithm of the observed values of average mass (mg) of glyphosate in the tanks without water hyacinth and with application of glyphosate.

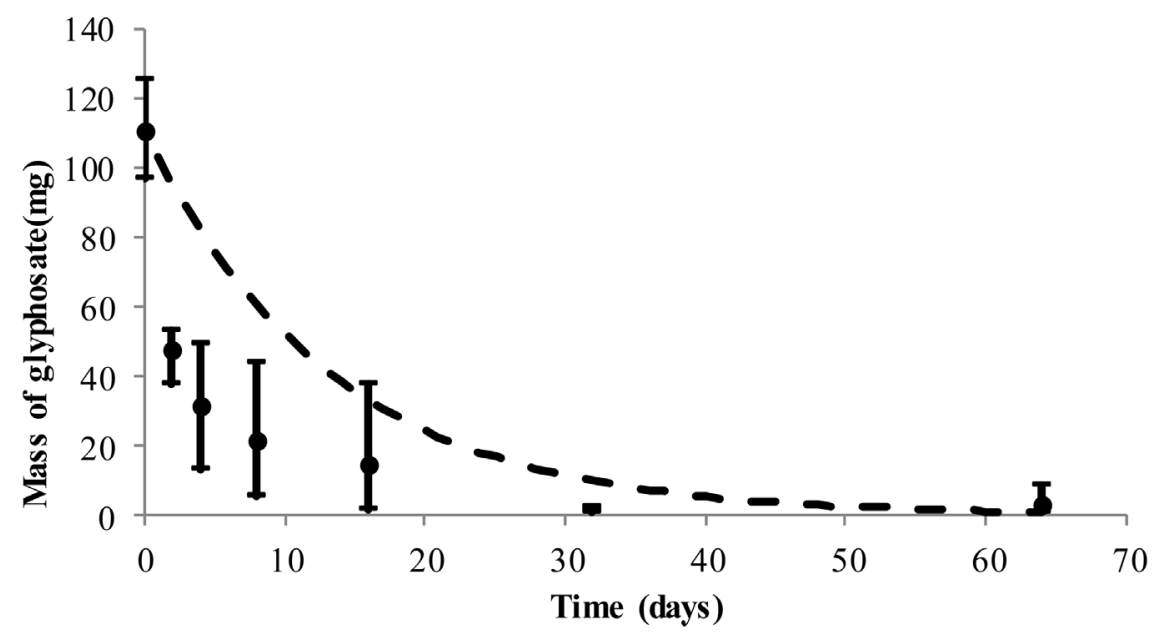

Figure 4. Observed and simulated values of average mass (mg) of glyphosate in the tanks without water hyacinth. Back symbols are values of average mass. Bars are values of average mass maximum and minimum. Dashed lines are simulated values of average mass.

\section{Conclusions}

The study has shown that glyphosate applied directly to the water surface or to controlling water hyacinth plants in closed aquatic environments is rapidly degraded and has no residues which would preclude its use. The average life of glyphosate in water for the control of macrophytes was estimated at 16 days and the decay calculated value was equal to 0.043 day $^{-1}$.

Therefore, the use of glyphosate in the control of aquatic plants can be recommended for use in continuous flow aquatic environments, since it has more favorable characteristics to dissipate and degrade herbicides, due to being less drastic than the one evaluated in this work.

\section{Acknowledgements}

We thank the School of Agricultural Engineering-University of Campinas and 
the Weed Science Center (NUPAM) of the College of Agricultural Sciences São Paulo State University for generous support in this project.

\section{References}

[1] Fairchild, F.J., Ruessler, D.S. and Carsol, A.R. (1998) Comparative Sensitivity of Five Species of Macrophytes and Six Species of Algae to Atrazine, Metribuzin, Alachlor, and Metolachlor. Environmental Toxicology and Chemistry, 17, 18301834.

[2] Velini, E.D. (2000) Aquatic Weeds Control. XXII Brazilian Congress of Weed Science, Lectures, SBCPD, Foz do Iguaçu, 137-147.

[3] Martins, D., Velini, E.D. and Negrisoli, E. (2005) Control of Egeria densa and Egeria najas in Water Tanks Using Diquat. Planta Daninha, 23, 381-385.

https://doi.org/10.1590/S0100-83582005000200029

[4] Martins, D. (1998) Aquatic Plants Control. Workshop Aquatic Plants Control, Brasília, Anais, IBAMA, 30-31.

[5] Pitelli, R.A., Martins, D. and Velini, E.D. (2008) Interference and Control of Aquatic Weeds. In: Vargas, L. and Roman, E.S., Eds., Manual Management and Weed Control, HRAC-BR, Passo Fundo, 299-328.

[6] Carvalho, F.T., Velini, E.D., Negrisoli, E. and Rossi, C.V.S. (2005) Efficiency of Carfentrazone-Ethyl in Controlling Large-Leafed Aquatic Plants Using Boxes of Water. Planta Daninha, 23, 305-310. https://doi.org/10.1590/S0100-83582005000200018

[7] Foloni, L.L. and Pitelli, R.A. (2005) Assessment of Sensitivity of Several Aquatic Weeds to Carfentrazone-Ethyl under Controlled Environment. Planta Daninha, 23, 329-334. https://doi.org/10.1590/S0100-83582005000200021

[8] Cícero, E.A.S., Pittelli, R.A., Sena, J.A.D. and Ferraudo, A.S. (2007) Genetic Variability and Sensitivity of Pistia stratiotes Accesses to Glyphosate. Planta Daninha, 25, 3, 579-587. https://doi.org/10.1590/S0100-83582007000300018

[9] Martins, D., Velini, E.D., Costa, N.V., Cardoso, L.A. and Souza, G.S.F. (2011) Chemical Control of Eichhornia crassipes and Brachiaria subquadripara with Diquat under Reservoir Conditions. Planta Daninha, 29, 51-57.

https://doi.org/10.1590/S0100-83582011000100006

[10] Velini, E.D., Negrisoli, E., Cavenaghi, A.L., Correa, M.R., Bravin, L.F.N., De March, S.R., Trindade, M.L.B., Arruda, D.P. and Padilha, F.S. (2005) Characterization of Water and Sediment Quality at the Americana Reservoir Related to the Occurrence of Aquatic Plants. Planta Daninha, 23, 215-223. https://doi.org/10.1590/S0100-83582005000200007

[11] Tanaka, R.H., Velini, E.D., Martins, D., Bronhara, A.A., Silva, M.A.S., Cavenaghi, A.L. and Tomazela, M.S. (2002) Efficacy of Fluridone in Controlling Egeria spp. in Tanks and in a Small Pond without Water Flow. Planta Daninha, 20, 73-81. (Special Edition)

[12] Marcondes, D.A.S., Velini, E.D., Martins, D., Tanaka, R.H., Carvalho, A.L., Cavenaghi, A.L. and Bronhara, A.A. (2002) Fluridone Efficacy in Controlling Submersed Aquatic Weeds and Its Effects on Some Environmental Characteristics. Planta Daninha, 20, 63-71. (Special Edition)

[13] Guimarães, G.L. (2003) Impacts of Macrophytes Control Using 2,4-D Herbicide on Mesocosms. Thesis (Doctorate in Agricultural Engineering), Faculty of Agricultural Engineering, State University of Campinas, Campinas.

[14] Martins, A.T. and Pitelli, R.A. (2005) Effects of Water Hyacinth Management on Water Quality under Mesocosmic Conditions. Planta Daninha, 23, 233-242. 
https://doi.org/10.1590/S0100-83582005000200009

[15] Negrisoli, E., Martins, D., Velini, E.D. and Ferreira, W.L.B. (2003) Diquat Degradation under Small-Tank Conditions with and without Egeria Plants. Planta Daninha, 21, 93-98. (Special Edition) https://doi.org/10.1590/S0100-83582003000400014

[16] Monsanto (1988) Herbicides to Aquatic Plants. Rodeo, Technical Manual.

[17] Brazilian Society of Weed Science-SBCPD (1995) Procedures for Installation, Evaluation and Analysis of Experiments with Herbicides, Londrina.

[18] Cruz, C., Nader Neto, A., Girio, A.C.F. and Pitelli, R.A. (2012) Efficacy of Glyphosate in Floating Macrophytes and Effects on Bioindicators. XXVIII Brazilian Congress of Weed Science, Campo Grande, 12-16.

[19] Paterson, M. (2004) Glyphosate Analysis of Risks to Endangered and Threatened Salmon and Steelhead. http://www.epa.gov/espp/litstatus/effects/glyphosate-analysis.pdf

[20] European Commission (2002) Review Report for the Active Substance Glyphosate. Finalised in the Standing Committee on Plant Health at its Meeting on 29 June 2001 in View of the Inclusion of Glyphosate in Annex I of Directive 91/414/EEC. European Commission, Health \& Consumer Protection Directorate-General, Brussels, $56 \mathrm{p}$.

[21] Battaglin, W.A., Kolpin, D.W., Scribner, E.A., Kuivila, K.M. and Sandstrom, M.W. (2005) Glyphosate, Others Herbicides, and Transformation Products in Midwestern Streams, 20021. Journal of the American Water Resources Association, 41, 323-332. https://doi.org/10.1111/j.1752-1688.2005.tb03738.x

[22] Estes, T.L. (2007) Estimation of Kinetic Parameters to Describe Dissipation of Glyphosate in Water-Sediment Systems, Using Data from Heintze, 1996. Monsanto Study XX-2005-066, Prepared by Stone Environmental Inc. Monsanto Company, St. Louis, Missouri, $61 \mathrm{p}$.

[23] Giesy, J.P., Dobson, S. and Solomon, K.R. (2000) Ecotoxicological Risk Assessment for Roundup Herbicide. In: Ware, G.W., Ed., Reviews of Environmental Contamination and Toxicology, Vol. 167, Springer, New York, 35-120. https://doi.org/10.1007/978-1-4612-1156-3_2

[24] Feng, J.C., Thompson, D.G. and Reynolds, P.E. (1990) Fate of Glyphosate in a Canadian Forest Watershed. Aquatic Residues and Off-Target Deposit Assessment. Journal of Agricultural and Food Chemistry, 38, 1110-1118. https://doi.org/10.1021/jf00094a045

[25] Goldsborough, L.G. and Brown, D.J. (1993) Dissipation of Glyphosate and Aminomethylphosphonic Acid in Water and Sediments of Boreal Forest Ponds. Environmental Toxicology and Chemistry, 12, 1139-1147. https://doi.org/10.1002/etc.5620120702

[26] FPPD (2012) Glyphosate. “Fooprint” Pesticide Properties Database. http://sitem.herts.ac.uk/aeru/footprint/index2.htm

[27] Mackay, D., Shiu, W., Ma, K.C. and Lee, S.C. (2006) Handbook of Physical-Chemical Properties and Environmental Fate for Organic Chemicals. 2nd Edition, CRC Press, Boca Raton.

[28] Ghassemi, M., Fargo, L., Painter, P. and Quinlivan, S. (1981) Environmental Fates and Impacts of Major Forest Use Pesticides. US Environmental Protection Agency, Office of Pesticides and Toxic Substances, Washington DC.

[29] Mercurio, P., Flores, F., Mueller, J.F., Carter, S. and Negri, A.P. (2014) Glyphosate Persistence in Seawater. Marine Pollution Bulletin, 85, 385-390.

[30] Mallat, E. and Barceló, D. (1998) Analysis and Degradation Study of Glyphosate 
and of Aminomethylphosphonic Acid in Natural Waters by Means of Polymeric and Ion-Exchange Solid-Phase Extraction Columns Followed by Ion Chromatography-Post-Column Derivatization with Fluorescence Detection. Journal of chromatography, 823, 129-136.

[31] Wang, S., Seiwert, B., Kästner, M., Miltner, A., Schäffer, A., Reemtsma, T., Yang, Q. and Nowak, K. (2016) (Bio)degradation of Glyphosate in Water-Sediment Microcosms-A Stable Isotope Co-Labeling Approach. Water Research, 99, 91-100.

[32] Centeno, A.J. (2009) Glyphosate: An Environmental Vision. In: Velini, E.D., Meschede, D.K., Carbonari, C.A. and Trindade, M.L.B., Eds., Glyphosate, Fepaf, Botucatu, 145-152.

[33] Pitelli, R.A. (2009) Glyphosate in the Control of Aquatic Weeds. In: Velini, E.D., Meschede, D.K., Carbonari, C.A. and Trindade, M.L.B., Eds., Glyphosate, Fepaf, Botucatu, 413-427.

Submit or recommend next manuscript to SCIRP and we will provide best service for you:

Accepting pre-submission inquiries through Email, Facebook, LinkedIn, Twitter, etc. A wide selection of journals (inclusive of 9 subjects, more than 200 journals)

Providing 24-hour high-quality service

User-friendly online submission system

Fair and swift peer-review system

Efficient typesetting and proofreading procedure

Display of the result of downloads and visits, as well as the number of cited articles Maximum dissemination of your research work

Submit your manuscript at: http://papersubmission.scirp.org/

Or contact jwarp@scirp.org 